This is an author produced version of a paper published in Inorganic Chemistry Frontiers.

This paper has been peer-reviewed but may not include the final publisher proof-corrections or pagination.

Citation for the published paper:

Alexandros Perivolaris, Constantinos C. Stoumpos, Jolanta Karpinska, Alan

G. Ryder, Jamie M. Frost, Kevin Mason, Alessandro Prescimone, Alexandra

M. Z. Slawin, Vadim G. Kessler, Euan K. Brechin, and Giannis S.

Papaefstathiou. (2014) A family of [Ni8] cages templated by $\mu 6$-peroxide from dioxygen activation. Inorganic Chemistry Frontiers. Volume: 1, Number: 6, pp 487-494.

http://dx.doi.org/10.1039/C4QI00048J.

Access to the published version may require journal subscription.

Published with permission from: Royal Society of Chemistry.

Epsilon Open Archive http://epsilon.slu.se 


\title{
A Family of $\left[\mathrm{Ni}_{8}\right]$ Cages Templated by $\mu_{6}$-peroxide from Dioxy- gen Activation
}

\author{
Alexandros Perivolaris, ${ }^{\dagger}$ Constantinos C. Stoumpos, ${ }^{\dagger}$ Jolanta Karpinska, ${ }^{\ddagger}$ Alan G. Ryder, ${ }^{\ddagger}$ Jamie \\ M. Frost, ${ }^{\S}$ Kevin Mason, ${ }^{\S}$ Alessandro Prescimone, ${ }^{\S}$ Alexandra M. Z. Slawin,, Vadim G. Kessler, ${ }^{\text {? }}$ \\ Euan K. Brechin $^{\S, *}$ and Giannis S. Papaefstathiou ${ }^{\dagger, *}$ \\ ${ }^{\dagger}$ Laboratory of Inorganic Chemistry, Department of Chemistry, National and Kapodistrian University of Athens, \\ Panepistimiopolis, 15771 Zografou, Greece. \\ ${ }^{\ddagger}$ Nanoscale Biophotonics Laboratory, School of Chemistry, National University of Ireland, Galway, Ireland. \\ ${ }^{\S}$ EaStCHEM School of Chemistry, The University of Edinburgh, West Mains Road, Edinburgh, EH9 3JJ, UK. \\ \# School of Chemistry, The University of St. Andrews, Purdie Building, St. Andrews, Fife KY16 9ST, UK. \\ ? Department of Chemistry, Swedish University of Agricultural Sciences, Box 7015, 750 o7 Uppsala, Sweden.
}

\begin{abstract}
A family of exceptionally thermally stable $\left[\mathrm{Ni}_{8}\right]$ cages is reported, each being templated by a rare $\eta^{3}: \eta^{3}: \mu_{6}-\mathrm{O}_{2}{ }^{2-}$ produced by dioxygen activation where the reducing agent for the $\mathrm{O}_{2}$ reduction appears to be the ligand used in the reaction mixtures which was found within the nickel cages in its oxidized form.
\end{abstract}

\section{INTRODUCTION}

Dioxygen activation has provided substantial impetus for important developments in several different fields. This includes biomimetic and bioinorganic chemistry which aims to reveal the structures of the reactive intermediates at the active sites of metalloenzymes and give insights into the mechanistic details of dioxygen activation and oxygenation reactions, ${ }^{1-6}$ and catalysis since the metaldioxygen intermediates have been proposed as active oxidants in $\mathrm{C}-\mathrm{H}$ bond activation reactions. ${ }^{3}$

It has been proposed that dioxygen activation first involves bonding of dioxygen at a reduced metal center to form metal-superoxo or metal-peroxo intermediates, followed by $\mathrm{O} \cdots \mathrm{O}$ bond cleavage leading to the formation of high-valent, metal-oxo species which are responsible for the oxidation reaction of the substrates within the metalloenzyme. ${ }^{1-6}$ It is therefore believed that the presence of a redox-active metal center is a fundamental prerequisite for activating and reducing dioxygen.

Indeed, over the years, several high-valent metalperoxo complexes, obtained by the act of dioxygen on a reduced metal center, have been structurally characterized by single-crystal X-ray crystallography. ${ }^{4}$ These examples include $\mathrm{Ti}(\mathrm{IV})$-peroxo, ${ }^{4 \mathrm{a}} \mathrm{V}(\mathrm{V})$-peroxo, ${ }^{4 \mathrm{~b}} \mathrm{Cr}(\mathrm{IV})$ peroxo, ${ }^{4 \mathrm{c}} \mathrm{Mn}(\mathrm{III})$-peroxo, ${ }^{4 \mathrm{~d}} \mathrm{Mn}(\mathrm{IV})$-peroxo, ${ }^{{ }^{\mathrm{e}}} \mathrm{Fe}(\mathrm{III})-$ peroxo, ${ }^{4 \mathrm{f}} \mathrm{Co}(\mathrm{III})$-peroxo ${ }^{4 \mathrm{~s}^{-4 \mathrm{k}}}$ and $\mathrm{Cu}(\mathrm{II})$-peroxo ${ }^{4,4 \mathrm{~m}}$ complexes that were isolated by the act of dioxygen on $\mathrm{Ti}_{2}(\mathrm{III}), \mathrm{V}(\mathrm{III}), \mathrm{Cr}(\mathrm{II}), \mathrm{Mn}(\mathrm{II}), \mathrm{Mn}(\mathrm{I}), \mathrm{Fe}(\mathrm{II}), \mathrm{Co}(\mathrm{II})$ and $\mathrm{Cu}(\mathrm{I})$ precursors, respectively.
Restricting further discussion to nickel-dioxygen species, there is only one $\mathrm{Ni}(\mathrm{II})$-peroxo ${ }^{5 \mathrm{a}}$ and one $\mathrm{Ni}$ (II)superoxo $^{5 \mathrm{~b}}$ compound obtained by the oxygenation of a $\mathrm{Ni}^{\mathrm{O}}$ and $\mathrm{Ni}^{\mathrm{l}}$ precursor, respectively, which have been structurally characterized. There are also few reports of spectroscopically characterized nickel-peroxo and nickelsuperoxo complexes obtained by the act of dioxygen on low-valent $\mathrm{Ni}^{\mathrm{O}}$ and $\mathrm{Ni}^{\mathrm{I}}$ precursors ${ }^{2 \mathrm{e}, 3 \mathrm{a}, 6}$ while there are not any structurally characterized $\mathrm{Ni}(\mathrm{II})$-peroxo species obtained by the act of dioxygen on $\mathrm{Ni}$ (II) centers.

Since $\mathrm{Ni}(\mathrm{II})$ is inert toward $\mathrm{O}_{2}$, the most common approach to obtain $\mathrm{Ni}(\mathrm{II})$-peroxo or $\mathrm{Ni}$ (II)-superoxo complexes is the use of $\mathrm{H}_{2} \mathrm{O}_{2} .^{5 b}$ Indeed, there are a handful of structurally characterized $\mathrm{Ni}(\mathrm{II})$-peroxo ${ }^{\mathrm{za}, \mathrm{b}}$ and $\mathrm{Ni}(\mathrm{II})$ superoxo ${ }^{7 \mathrm{c}, \mathrm{d}}$ species obtained by the reaction of $\mathrm{H}_{2} \mathrm{O}_{2}$ with $\mathrm{Ni}(\mathrm{II})$ or $\mathrm{Ni}(\mathrm{III})$ precursors, respectively. It is worth noting that one $\mathrm{Ni}(\mathrm{II})$-peroxo complex ${ }^{8}$ has been obtained by the chemical reduction of a $\mathrm{Ni}(\mathrm{II})$-superoxo precursor, ${ }^{5 \mathrm{~b}}$ with the latter being originally synthesized by the reaction of a $\mathrm{Ni}(\mathrm{I})$ precursor with $\mathrm{O}_{2}$.

We herein report a family of $\left[\mathrm{Ni}^{\mathrm{II}}{ }_{8}\right]$ cages templated by a rare $\eta^{3}: \eta^{3}: \mu_{6}-\mathrm{O}_{2}{ }^{2-}$ species produced by dioxygen reduction. Although we cannot ignore the presence of the $\mathrm{Ni}(\mathrm{II})$ ions, which might indeed be involved in the dioxygen activation, the reducing agent for the $\mathrm{O}_{2}$ reduction appears to be the ligand used in the reaction mixtures, which was found within the nickel cages in its oxidized form. Specifically, three octanuclear $\mathrm{Ni}(\mathrm{II})$ cages, namely $\left[\mathrm{Ni}_{8}\left(\mathrm{O}_{2}\right)(\mathrm{abmo})_{6}\left(\mathrm{MeCO}_{2}\right)_{2}(\mathrm{MeO})_{6}(\mathrm{MeOH})_{4}\right] \cdot 4 \mathrm{H}_{2} \mathrm{O} \mathbf{1} \cdot 4 \mathrm{H}_{2} \mathrm{O}$, $\left[\mathrm{Ni}_{8}\left(\mathrm{O}_{2}\right)(\mathrm{abmo})_{6}\left(\mathrm{PhCO}_{2}\right)_{2}(\mathrm{MeO})_{6}(\mathrm{MeOH})_{4}\right] \cdot 2 \mathrm{MeOH} \quad \mathbf{2 \cdot 2}$ $\mathrm{MeOH}$ and $\left[\mathrm{Ni}_{8}\left(\mathrm{O}_{2}\right)(\mathrm{abmo})_{6}\left(4 \mathrm{ClPhCO}_{2}\right)_{2}(\mathrm{MeO})_{6}(\mathrm{MeOH})_{2}\right.$ 
$\left.\left(\mathrm{H}_{2} \mathrm{O}\right)_{2}\right]$ 3, $(\mathrm{abmoH}=\alpha$-benzilmonoxime, Chart 1) were isolated from the reaction of nickel(II) carboxylates with $\alpha$-benzoin oxime $\left(\mathrm{aboH}_{2}\right.$, Chart 1$)$ in $\mathrm{MeOH}$ under aerobic conditions. Interestingly, abmoH is the oxidized form of $\mathrm{aboH}_{2}$. Direct evidence that the peroxide originates from the dioxygen reduction was provided by the act of ${ }^{18} \mathrm{O}_{2}$ in a deoxygenated reaction mixture of 2 . To the best of our knowledge, complexes 1-3 represent the first examples of structurally characterized $\mathrm{Ni}(\mathrm{II})$-peroxo complexes obtained by the act of dioxygen on $\mathrm{Ni}(\mathrm{II})$ precursors.

Chart 1. The structures of $\alpha$-benzoin oxime $\left(\mathrm{aboH}_{2}\right)$ and $\alpha$-benzilmonoxime (abmoH).
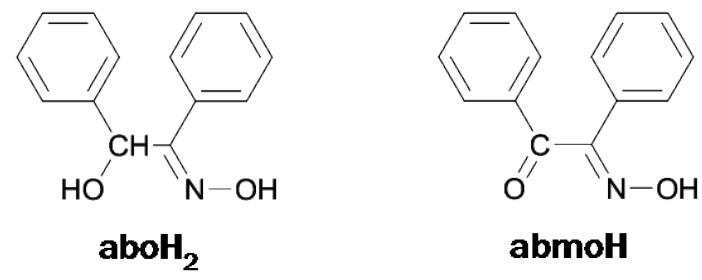

Such a dioxygen reduction where both the peroxide, $\mathrm{O}_{2}{ }^{2-}$, (i.e. the reduced species) and the oxidized species (i.e. the $\mathrm{abmo}^{-}$) are isolated and structurally characterized in the final product, and in which the metal ion appears not to change its oxidation state, has never been observed. This means that the electrons needed to reduce the dioxygen into the $\mathrm{O}_{2}{ }^{2-}$ are provided by the organic ligand (i.e. not the metal ion). The significance of these findings is that it provides evidence that the dioxygen activation and its subsequent reduction may also depend on the organic surroundings of the metal-containing active site of metalloenzymes. ${ }^{1,2 s, 2 t, 2 x}$ Nevertheless, there are few reports of structurally characterized metal-peroxo complexes obtained by dioxygen reduction where the metal center does not change oxidation state, but the reducing agent was not identified. ${ }^{9}$ The same $\left[\mathrm{Ni}_{8}\right]$ cages can be isolated from the reaction of nickel(II) carboxylates with abmoH, but only when $\mathrm{H}_{2} \mathrm{O}_{2}$ is added into the reaction mixtures. One side product, namely $\left[\mathrm{Ni}_{5}(\mathrm{abo})_{2}(\mathrm{aboH})_{6}\right] \cdot 4 \mathrm{MeOH} \cdot \mathrm{CH}_{2} \mathrm{Cl}_{2} 4 \cdot 4 \mathrm{MeOH} \cdot \mathrm{CH}_{2} \mathrm{Cl}_{2}$ was also isolated and characterized by $\mathrm{X}$-ray crystallography. To the best of our knowledge cages 1-3 represent the first polynuclear metal complexes which can be synthesized from different organic ligands (i.e. $\mathrm{aboH}_{2}$ and $\mathrm{abmoH}$ ).

\section{EXPERIMENTAL SECTION}

Materials and Methods. $\mathrm{Ni}\left(\mathrm{MeCO}_{2}\right)_{2} \cdot 4 \mathrm{H}_{2} \mathrm{O}, \mathrm{aboH}_{2}(\alpha-$ benzoin oxime) $\mathrm{H}_{2} \mathrm{O}_{2}, \mathrm{Et}_{3} \mathrm{~N}, \mathrm{KBr},{ }^{18} \mathrm{O}_{2}$ (90\%, ${ }^{18} \mathrm{O}$-enriched) and $\mathrm{H}_{2}{ }^{18} \mathrm{O}_{2}$ (2-3\% solution, 90\% ${ }^{18} \mathrm{O}$-enriched) and all solvents were purchased from commercial sources and used as received. $\mathrm{Ni}\left(\mathrm{PhCO}_{2}\right)_{2} \cdot 3 \mathrm{H}_{2} \mathrm{O},{ }^{10} \quad \mathrm{Ni}\left(4 \mathrm{ClPhCO}_{2}\right)_{2}{ }^{10}$ $\left({ }_{4} \mathrm{ClPhCO}_{2} \mathrm{H}=4\right.$-chloro-benzoic acid) and $\mathrm{abmoH}^{11}(\alpha-$ benzilmonoxime) were prepared according to literature procedures. IR spectra were recorded as $\mathrm{KBr}$ pellets in the $4000-400 \mathrm{~cm}^{-1}$ range on a Shimadzu FT/IR IRAffinity-1 spectrometer. TGA data were collected with a Mettler Toledo TGA/DCS1 instrument in $40 \mu \mathrm{l} \mathrm{Al}$ pans under a $\mathrm{N}_{2}$ flow of $50 \mathrm{ml} \mathrm{min}^{-1}$. Small sample portions ( 1-2 $\mathrm{mg}$ ) were used to avoid damage of the instrument due to the explo- sive nature of the peroxide complexes. Variabletemperature, solid-state direct current (dc) magnetic susceptibility data down to $5 \mathrm{~K}$ were collected on a Quantum Design MPMS-XL SQUID magnetometer equipped with a 7 T dc magnet. Diamagnetic corrections were applied to the observed paramagnetic susceptibilities using Pascal's constants.

X-ray Crystallography. Data collection parameters and structure solution and refinement details are listed in Table 1. Full details for 1-4 can be found in the CIF files provided in the Supporting Information. Full crystallographic data for complexes 1-4 were collected from singlecrystals obtained from $\mathrm{aboH}_{2}$ (see Syntheses below). The structures of single-crystals obtained from abmoH were confirmed by measuring the cell dimensions.

Raman Spectroscopy. Raman spectra were collected for all samples on two different Raman spectrometers, both with $785 \mathrm{~nm}$ excitation. First a Raman WorkStation $^{\mathrm{TM}}$ (Kaiser Optical Systems Inc., Ann Arbor, MI) over a 200-3000 $\mathrm{cm}^{-1}$ spectral range, with a resolution of $\sim 3-4 \mathrm{~cm}^{-1}$. This system was equipped with a $-40^{\circ} \mathrm{C}$ cooled CCD detector. The second system was a RamanStation spectrometer (AVALON Instruments Ltd, Belfast) equipped with a TE cooled $\left(-90{ }^{\circ} \mathrm{C}\right)$ back thinned $\mathrm{CCD}$ detector. A laser power of $\sim 70 \mathrm{~mW}$ (at the sample) with an exposure time of $2 \times 10$ seconds was generally used and spectra were collected from 250 to $3311 \mathrm{~cm}^{-1}$ (at a resolution of $4 \mathrm{~cm}^{-1}$ ). For all data, exposure times (between 10 and 45 seconds) and accumulation numbers were varied in order to try and attain the optimal signal to noise $(\mathrm{S} / \mathrm{N})$ ratio in the Raman spectra so that any shifts in the peroxo bonds could be accurately measured. The spectra were not corrected for instrument response.

Mass spectrometry. The analysis was carried out using a Bruker Maxis Impact instrument with an electrospray (ESI-MS) ionisation source. The calibration solution used was Agilent ESI-L low concentration tuning mix solution, Part No. G1969-8500o, enabling calibration between approximately $50 \mathrm{~m} / \mathrm{z}$ and $2000 \mathrm{~m} / \mathrm{z}$. Samples were dissolved in $\mathrm{CH}_{2} \mathrm{Cl}_{2} / \mathrm{CH}_{3} \mathrm{OH}$ at concentrations of $10^{-4}$ $\mathrm{molL}^{-1}$ and introduced into the MS at a dry gas temperature of $180{ }^{\circ} \mathrm{C}$. The ion polarity for all MS scans recorded was positive, with the voltage of the capillary tip set at $4000 \mathrm{~V}$, end plate offset at $-500 \mathrm{~V}$, funnel $1 \mathrm{RF}$ at $400 \mathrm{Vpp}$ and funnel $2 \mathrm{RF}$ at $400 \mathrm{Vpp}$, hexapole RF at $200 \mathrm{Vpp}$, ion energy $5 \mathrm{eV}$, collision energy at $5 \mathrm{eV}$, collision cell RF at $1500 \mathrm{Vpp}$, transfer time at $\mathbf{1 2 0 . 0} \mu \mathrm{s}$ and the pre-pulse storage time at $10.0 \mu \mathrm{s}$. Each spectrum was collected for 2 mins.

\section{Syntheses}

$$
\begin{gathered}
{\left[\mathrm{Ni}_{8}\left(\mathrm{O}_{2}\right)(\mathrm{abmo})_{6}\left(\mathrm{MeCO}_{2}\right)_{2}(\mathrm{MeO})_{6}(\mathrm{MeOH})_{4}\right] \cdot 4 \mathrm{H}_{2} \mathrm{O}} \\
\left(1 \cdot 4 \mathrm{H}_{2} \mathrm{O}\right) \text { and }\left[\mathrm{Ni}_{5}(\mathrm{abo})_{2}(\mathrm{aboH})_{6}\right] \cdot 4 \mathrm{MeOH} \cdot \mathrm{CH}_{2} \mathrm{Cl}_{2}
\end{gathered}
$$
$\left(4 \cdot 4 \mathrm{MeOH} \cdot \mathbf{C H}_{2} \mathbf{C l}_{2}\right.$ ) from $\mathbf{a b o H}_{2}$. To a slurry of $\mathrm{Ni}\left(\mathrm{MeCO}_{2}\right)_{2} \cdot 4 \mathrm{H}_{2} \mathrm{O}(0.4 \mathrm{mmol})$ and $\mathrm{aboH}_{2}(0.4 \mathrm{mmol})$ in $\mathrm{MeOH}(25 \mathrm{~mL})$ was added a $1 \mathrm{M} \mathrm{Et}_{3} \mathrm{~N}$ solution in $\mathrm{EtOH}$ (o.8 mmol). The slurry was stirred for 4 hours, during which time an orange-yellow precipitate formed in $\sim 20 \%$ yield (based on $\mathrm{Ni}$ ). The precipitate was filtered and the dark 
green-brown filtrate left undisturbed for 4 days. Dark green single crystals of $\mathbf{1} \cdot 4 \mathrm{H}_{2} \mathrm{O}$ were formed in $\sim 55 \%$ yield (based on $\mathrm{Ni}$ ). The crystals were collected by vacuum filtration, washed with a small amount of $\mathrm{MeOH}$ and $\mathrm{Et}_{2} \mathrm{O}$ and dried in air. Recrystallization of the orange-yellow powder from $\mathrm{CH}_{2} \mathrm{Cl}_{2} / \mathrm{MeOH}$ afforded orange-yellow crystals of $4 \cdot 4 \mathrm{MeOH} \cdot \mathrm{CH}_{2} \mathrm{Cl}_{2}$. Elemental analysis for $\mathbf{1} \cdot 4 \mathrm{H}_{2} \mathrm{O}$ (\%) calcd for $\mathrm{C}_{98} \mathrm{H}_{108} \mathrm{~N}_{6} \mathrm{O}_{32} \mathrm{Ni}_{8}: \mathrm{C}_{5} \mathrm{O} .05, \mathrm{H} 4.63, \mathrm{~N}$ 3.57; found: $\mathrm{C} 50.10, \mathrm{H} 4.50, \mathrm{~N} 3.53$. Elemental analysis for $4 \cdot 4 \mathrm{MeOH} \cdot \mathrm{CH}_{2} \mathrm{Cl}_{2}$ (\%) calcd for $\mathrm{C}_{117} \mathrm{H}_{112} \mathrm{~N}_{8} \mathrm{O}_{20} \mathrm{Cl}_{2} \mathrm{Ni}_{5}$ : C 6o.71, $\mathrm{H} 4.88, \mathrm{~N} 4.84$; found: $\mathrm{C} 60.69, \mathrm{H} 4.82, \mathrm{~N} 4.80$. IR for $1 \cdot 4 \mathrm{H}_{2} \mathrm{O}, \mathrm{cm}^{-1}$ ( $\mathrm{KBr}$ pellets): $3052 \mathrm{w}, 2923 \mathrm{w}, 2810 \mathrm{w}, 1583$ s, 1551 s, 1444 sh, 1407 s, 1344 s, 1286 s, 1268 s, 1194 s, 1176 s, $1098 \mathrm{w}, 1052 \mathrm{~m}, 1025$ s, $999 \mathrm{w}, 917 \mathrm{~s}, 793 \mathrm{br}, 745 \mathrm{~m}, 719 \mathrm{w}$, $696 \mathrm{sh}, 680 \mathrm{~m}, 642 \mathrm{w}, 618 \mathrm{w}, 582 \mathrm{w}, 439$ br. IR for 4.4 MeOH. $\mathrm{CH}_{2} \mathrm{Cl}_{2}, \mathrm{~cm}^{-1}$ (KBr pellets): $1705 \mathrm{br}, 1492 \mathrm{sh}, 1452$ sh, 1444 sh, 1138 br, 1111 br, 1069 sh, 1042 w br 1018 w br, 917 $\mathrm{w}, 835 \mathrm{w}$.

$\left[\mathrm{Ni}_{8}\left(\mathrm{O}_{2}\right)(\mathrm{abmo})_{6}\left(\mathrm{PhCO}_{2}\right)_{2}(\mathrm{MeO})_{6}(\mathrm{MeOH})_{4}\right] \cdot 2 \mathrm{MeOH}$ $(2 \cdot 2 \mathrm{MeOH})$ and $\left[\mathrm{Ni}_{8}\left(\mathrm{O}_{2}\right)(\mathrm{abmo})_{6}\left({ }_{4} \mathrm{ClPhCO}_{2}\right)_{2}(\mathrm{MeO})_{6}\right.$ $\left.(\mathrm{MeOH})_{2}\left(\mathrm{H}_{2} \mathrm{O}\right)_{2}\right](3)$ along with (4) were prepared in a similar manner with the above synthesis by replacing $\mathrm{Ni}\left(\mathrm{MeCO}_{2}\right)_{2} \cdot 4 \mathrm{H}_{2} \mathrm{O}$ with $\mathrm{Ni}\left(\mathrm{PhCO}_{2}\right)_{2} \cdot 3 \mathrm{H}_{2} \mathrm{O}$ and $\mathrm{Ni}\left({ }_{4} \mathrm{ClPhCO}_{2}\right)_{2}$, respectively. The relevant yields for 2.2 $2 \mathrm{MeOH}$ and 4 were $60 \%$ and $15 \%$, respectively, while those for 3 and 4 were $65 \%$ and $12 \%$, respectively. Elemental analysis for $\mathbf{2} \cdot 2 \mathrm{MeOH}$ (\%) calcd for $\mathrm{C}_{110} \mathrm{H}_{112} \mathrm{~N}_{6} \mathrm{Ni}_{8} \mathrm{O}_{30}$ : C 53.54, H 4.57, N 3.41; found: $\mathrm{C} 53.5 \mathrm{o}, \mathrm{H}$ 4.53, N 3.44. IR for $2.2 \mathrm{MeOH}, \mathrm{cm}^{-1}$ (KBr pellets): $3049 \mathrm{w}$, 2917 w, 2812 w, 1588 s, 1547 s, 1444 sh, 1393 s, 1345 s, 1286 s, 1268 s, 1194 s, 1176 s, 1099 w, 1051 m, 1024 s, 998 w, 916 s, $800 \mathrm{w}, 746 \mathrm{~m}, 719 \mathrm{~m}, 696 \mathrm{sh}, 679 \mathrm{~m}, 640 \mathrm{w}, 620 \mathrm{w}, 582 \mathrm{w}$, 434 br. Elemental analysis for 3 (\%) calcd for $\mathrm{C}_{106} \mathrm{H}_{98} \mathrm{Cl}_{2} \mathrm{~N}_{6} \mathrm{Ni}_{8} \mathrm{O}_{28}$ : C 52.08, H 4.04, N 3.44; found: $\mathrm{C}$ 50.05, H 4.00, N 3.49. IR for 3, $\mathrm{cm}^{-1}$ ( $\mathrm{KBr}$ pellets): $3055 \mathrm{w}$, $2920 \mathrm{w}, 2813 \mathrm{w}, 1587 \mathrm{~s}, 1546 \mathrm{~s}, 1444$ m, 1396 s, 1345 s, 1286 s, 1269 s, 1193 s, 1176 s, 1096 w, 1051 m, 1027 m, 998 w, 916 s, $798 \mathrm{w}, 775 \mathrm{w}, 746 \mathrm{~m}, 718 \mathrm{w}, 696 \mathrm{sh}, 688 \mathrm{w}, 582 \mathrm{w}, 439$ br.

$\left[\mathrm{Ni}_{8}\left(\mathrm{O}_{2}\right)(\mathrm{abmo})_{6}\left(\mathrm{MeCO}_{2}\right)_{2}(\mathrm{MeO})_{6}(\mathrm{MeOH})_{4}\right] \cdot 4 \mathrm{H}_{2} \mathrm{O}$ $\left(\mathbf{1} \cdot 4 \mathrm{H}_{2} \mathrm{O}\right)$ from abmoH. To a slurry of $\mathrm{Ni}\left(\mathrm{MeCO}_{2}\right)_{2} \cdot 4 \mathrm{H}_{2} \mathrm{O}$ (0.4 mmol) and abmoH (0.4 mmol) in $\mathrm{MeOH}(25 \mathrm{~mL})$ were added $\mathrm{H}_{2} \mathrm{O}_{2}(30 \%$ solution, $0.4 \mathrm{mmol})$ and $\mathrm{Et}_{3} \mathrm{~N}(\mathrm{MM}$ solution in EtOH, o.8 mmol). The slurry was stirred for 1 hour. The resulting dark green-brown solution was left undisturbed for 4 days. Dark green single crystals of $\mathbf{1} \cdot 4 \mathrm{H}_{2} \mathrm{O}$ were formed in $\sim 75 \%$ yield (based on $\mathrm{Ni}$ ). The crystals were collected by vacuum filtration, washed with a small amount of $\mathrm{MeOH}$ and $\mathrm{Et}_{2} \mathrm{O}$ and dried in air. Elemental analysis for $\mathbf{1} \cdot 4 \mathrm{H}_{2} \mathrm{O}$ (\%) calcd for $\mathrm{C}_{98} \mathrm{H}_{108} \mathrm{~N}_{6} \mathrm{O}_{32} \mathrm{Ni}_{8}: \mathrm{C}$ 50.05, H 4.63, N 3.57; found: $\mathrm{C} 50.12, \mathrm{H}$ 4.53, $\mathrm{N}$ 3.52. IR for $\mathbf{1} \cdot 4 \mathrm{H}_{2} \mathrm{O}, \mathrm{cm}^{-1}$ (KBr pellets): $3052 \mathrm{w}, 2923$ w, 2810 w, 1583 s, 1551 s, 1444 sh, 1407 s, 1344 s, 1286 s, 1268 s, 1194 s, 1176 s, 1098 w, 1052 m, 1025 s, 999 w, 917 s, 793 br, $745 \mathrm{~m}, 719 \mathrm{w}, 696 \mathrm{sh}, 68 \mathrm{o} \mathrm{m}, 642 \mathrm{w}, 618 \mathrm{w}, 582 \mathrm{w}, 439 \mathrm{br}$.

$\left[\mathrm{Ni}_{8}\left(\mathrm{O}_{2}\right)(\mathrm{abmo})_{6}\left(\mathrm{PhCO}_{2}\right)_{2}(\mathrm{MeO})_{6}(\mathrm{MeOH})_{4}\right] \cdot 2 \mathrm{MeOH}$ $(2 \cdot 2 \mathrm{MeOH})$ and $\left[\mathrm{Ni}_{8}\left(\mathrm{O}_{2}\right)(\mathrm{abmo})_{6}\left({ }_{4} \mathrm{ClPhCO}_{2}\right)_{2}(\mathrm{MeO})_{6}\right.$ $\left.(\mathrm{MeOH})_{2}\left(\mathrm{H}_{2} \mathrm{O}\right)_{2}\right](3)$ were prepared in a similar manner with the above synthesis by replacing $\mathrm{Ni}\left(\mathrm{MeCO}_{2}\right)_{2} \cdot 4 \mathrm{H}_{2} \mathrm{O}$ with $\mathrm{Ni}\left(\mathrm{PhCO}_{2}\right)_{2} \cdot 3 \mathrm{H}_{2} \mathrm{O}$ and $\mathrm{Ni}\left(4 \mathrm{ClPhCO}_{2}\right)_{2}$, respectively.
The relevant yields for $\mathbf{2} \cdot 2 \mathrm{MeOH}$ and $\mathbf{3}$ were $77 \%$ and $79 \%$, respectively. Elemental analysis for $2 \cdot 2 \mathrm{MeOH}(\%)$ calcd for $\mathrm{C}_{110} \mathrm{H}_{112} \mathrm{~N}_{6} \mathrm{Ni}_{8} \mathrm{O}_{30}: \mathrm{C}_{53.54} \mathrm{H} 4.57, \mathrm{~N} 3.41$; found: $\mathrm{C}$ 53.52, $\mathrm{H} 4.54, \mathrm{~N} 3.43$. IR for $2 \cdot 2 \mathrm{MeOH}, \mathrm{cm}^{-1}$ ( $\mathrm{KBr}$ pellets): 3049 w, 2917 w, 2812 w, 1588 s, 1547 s, 1444 sh, 1393 s, 1345 s, 1286 s, 1268 s, 1194 s, 1176 s, 1099 w, 1051 m, 1024 s, 998 w, $916 \mathrm{~s}, 800 \mathrm{w}, 746 \mathrm{~m}, 719 \mathrm{~m}, 696 \mathrm{sh}, 679 \mathrm{~m}, 640 \mathrm{w}, 620$ w, $582 \mathrm{w}, 434 \mathrm{br}$. Elemental analysis for 3 (\%) calcd for $\mathrm{C}_{106} \mathrm{H}_{98} \mathrm{Cl}_{2} \mathrm{~N}_{6} \mathrm{Ni}_{8} \mathrm{O}_{28}$ : C 52.08, $\mathrm{H}$ 4.04, $\mathrm{N}$ 3.44; found: $\mathrm{C}$ 50.07, $\mathrm{H} 4.02, \mathrm{~N} 3.45$. IR for 3, $\mathrm{cm}^{-1}$ (KBr pellets): $3055 \mathrm{w}$, $2920 \mathrm{w}, 2813 \mathrm{w}, 1587 \mathrm{~s}, 1546 \mathrm{~s}, 1444 \mathrm{~m}, 1396 \mathrm{~s}, 1345$ s, 1286 s, 1269 s, 1193 s, 1176 s, 1096 w, 1051 m, 1027 m, 998 w, 916 s, $798 \mathrm{w}, 775 \mathrm{w}, 746 \mathrm{~m}, 718 \mathrm{w}, 696 \mathrm{sh}, 688 \mathrm{w}, 582 \mathrm{w}, 439 \mathrm{br}$.

$\left[\mathrm{Ni}_{8}\left({ }^{18} \mathrm{O}_{2}\right)(\mathrm{abmo})_{6}\left(\mathrm{PhCO}_{2}\right)_{2}(\mathrm{MeO})_{6}(\mathrm{MeOH})_{4}\right] \cdot 2 \mathrm{MeO}$ $\mathrm{H}(2 \mathrm{~A} \cdot 2 \mathrm{MeOH})$ from $\mathrm{aboH}_{2}$ and ${ }^{18} \mathrm{O}_{2}$. Manipulations were performed under argon in deoxygenated solvents using standard Schlenk techniques. To a slurry of $\mathrm{Ni}\left(\mathrm{PhCO}_{2}\right)_{2} \cdot 3 \mathrm{H}_{2} \mathrm{O}(0.4 \mathrm{mmol})$ and $\mathrm{aboH}_{2}(0.4 \mathrm{mmol})$ in deoxygenated $\mathrm{MeOH}(25 \mathrm{~mL})$ was added a $1 \mathrm{M} \mathrm{Et}_{3} \mathrm{~N}$ solution in EtOH (o.8 mmol). The slurry was stirred for 1 hour, during which time an orange-yellow precipitate formed in $\sim 20 \%$ yield (based on $\mathrm{Ni}$ ). The precipitate was filtered and the green filtrate was bubbled with a $250 \mathrm{~mL}$ of ${ }^{18} \mathrm{O}_{2}$ (90\%, ${ }^{18} \mathrm{O}$-enriched). The solution turned darkgreen brown and left undisturbed for 4 days. Dark green single crystals of $\mathbf{2} \mathbf{A} \cdot 2 \mathrm{MeOH}$ were formed in $\sim 63 \%$ yield (based on $\mathrm{Ni}$ ). The crystals were collected by vacuum filtration, washed with a small amount of $\mathrm{MeOH}$ and $\mathrm{Et}_{2} \mathrm{O}$ and dried in air. Analytical data, as well as IR data were identical to those of $\mathbf{2} \cdot \mathbf{2} \mathrm{MeOH}$.

$\left[\mathrm{Ni}_{8}\left({ }^{18} \mathrm{O}_{2}\right)(\mathrm{abmo})_{6}\left(\mathrm{PhCO}_{2}\right)_{2}(\mathrm{MeO})_{6}(\mathrm{MeOH})_{4}\right] \cdot 2 \mathrm{MeO}$ $\mathrm{H}(\mathbf{2 A} \cdot \mathbf{2 M e O H})$ from abmoH and $\mathrm{H}_{2}{ }^{18} \mathrm{O}_{2}$. To a slurry of $\mathrm{Ni}\left(\mathrm{PhCO}_{2}\right)_{2} \cdot 3 \mathrm{H}_{2} \mathrm{O}(0.4 \mathrm{mmol})$ and abmoH $(0.4 \mathrm{mmol})$ in $\mathrm{MeOH}(25 \mathrm{~mL})$ were added $\mathrm{H}_{2}{ }^{18} \mathrm{O}_{2}$ (2-3\% solution, $90 \%$ ${ }^{18} \mathrm{O}$-enriched, $100 \mathrm{mg}$ ) and $\mathrm{Et}_{3} \mathrm{~N}$ (1M solution in $\mathrm{EtOH}$, o.8 $\mathrm{mmol}$ ). The slurry was stirred for 1 hour. The resulting dark green-brown solution was left undisturbed for 4 days. Dark green single crystals of $\mathbf{2} \mathbf{A} \cdot \mathbf{2} \mathrm{MeOH}$ were formed in $\sim 70 \%$ yield (based on $\mathrm{Ni}$ ). The crystals were collected by vacuum filtration, washed with a small amount of $\mathrm{MeOH}$ and $\mathrm{Et}_{2} \mathrm{O}$ and dried in air. Analytical data, as well as IR data were identical to those of 2.2 $\mathrm{MeOH}$.

\section{RESULTS AND DISCUSSION}

Syntheses. The reaction of $\mathrm{Ni}\left(\mathrm{MeCO}_{2}\right)_{2} \cdot 4 \mathrm{H}_{2} \mathrm{O}$ with $\mathrm{aboH}$ in $\mathrm{MeOH}$ and in the presence of triethylamine $\left(\mathrm{Et}_{3} \mathrm{~N}\right)$ at room temperature results in a yellow-orange powder and a dark green-brown solution. Recrystallization of the yellow-orange powder revealed the pentanuclear complex 4 , while slow evaporation of the dark green-brown solution afforded X-ray quality dark green crystals of 1. Similar reactions involving $\mathrm{Ni}\left(\mathrm{PhCO}_{2}\right)_{2} \cdot 3 \mathrm{H}_{2} \mathrm{O}$ or $\mathrm{Ni}\left(4 \mathrm{ClPhCO}_{2}\right)_{2}$ resulted in the same yellow-orange powder and $\mathrm{X}$-ray quality dark green crystals of 2 and 3, respectively. The identity of the products is independent of the metal to ligand ratio. Performing the same reactions at elevated temperatures (i.e. above $50{ }^{\circ} \mathrm{C}$ ) substantially reduces the yield of complex 4 and increases the yields of complexes 
1-3. With the structures of complexes 1-3 known, we repeated the same reactions in the absence of $\mathrm{O}_{2}$ : in this case only complex 4 forms and the solution does not turn dark green-brown, but retains its original green colour. In order to provide direct evidence that the $\mu_{6}-\mathrm{O}_{2}{ }^{2-}$ originates from the reduction of dioxygen we synthesized the ${ }^{18} \mathrm{O}$-labelled complex $2(\mathbf{2 A})$ by the act of ${ }^{18} \mathrm{O}_{2}$ in a dioxygenated reaction mixture of $\mathbf{2}$. The ${ }^{18} \mathrm{O}$-labbeled $\mathbf{2 A}$ was obtained and characterized by Raman spectroscopy. Non of the bands in the recorded spectra were sensitive to isotopic substitution of the peroxide, therefore we also performed ESI-MS on both unlabelled 2 and ${ }^{18} \mathrm{O}$-labbeled 2A where we observed a 4 units shift correlating to the labelling of both oxygens of the peroxo ligand. Having established the presence of the $\mathrm{abmo}^{-}$ligands within the cages of 1-3, we attempted to isolate these complexes starting from abmoH instead of $\mathrm{aboH}_{2}$. The solution does not turn dark green-brown until $\mathrm{H}_{2} \mathrm{O}_{2}$ is added to the reaction mixture in each case. $A s$ in the $\mathrm{Ni}\left(\mathrm{RCO}_{2}\right)_{2} / \mathrm{aboH}_{2} / \mathrm{Et}_{3} \mathrm{~N}$ reaction system, the reactions of $\mathrm{Ni}\left(\mathrm{RCO}_{2}\right)_{2}$ with abmoH and $\mathrm{H}_{2} \mathrm{O}_{2}$ in $\mathrm{MeOH}$ in the presence of $\mathrm{Et}_{3} \mathrm{~N}$ results in dark green-brown solutions from which complexes 1-3 were isolated and their structures were re-confirmed by single-crystal X-ray crystallography. The ${ }^{18} \mathrm{O}$-labbeled $\mathbf{2 A}$ was also synthesized by adding $\mathrm{H}_{2}^{18} \mathrm{O}_{2}$ in a reaction mixture of $\mathrm{Ni}\left(\mathrm{PhCO}_{2}\right)_{2} \cdot 3 \mathrm{H}_{2} \mathrm{O}$ $/ \mathrm{abmoH} / \mathrm{Et}_{3} \mathrm{~N}$.

Description of structures. Although complexes 1-3 are not isostructural, their molecular structures are very similar. A labeled plot of representative complex 1, whose structure will be discussed in detail, is shown in Figure 1 (see Supporting Information for figures of complexes 2 and 3).

Complex 1 crystallizes in the triclinic space group $P-1$. The $\left[\mathrm{Ni}_{8}\right]$ cage is situated on a center of inversion and consists of a $\mathrm{Ni}_{6}\left(\mathrm{O}_{2}\right)$ core with staggered symmetry $\left(D_{3 \mathrm{~d}}\right)$. The six $\mathrm{Ni}^{\mathrm{II}}$ ions are situated at the apices of a distorted octahedron, with the $\mathrm{Ni} \cdots \mathrm{Ni}$ separations ranging from 3.362 to $4.856 \AA$. The octahedron is doubly face-capped by the remaining two $\mathrm{Ni}^{\mathrm{il}}$ ions ( $\mathrm{Ni}_{4}$ and $\mathrm{Ni}_{4}$ '). All $\mathrm{Ni}^{\mathrm{II}}$ ions are in distorted octahedral geometries. Six abmo ligands bridge the central $\mathrm{Ni}_{6}$ core in a $\eta^{1}: \eta^{1}: \eta^{1}: \mu$-fashion, with each abmo ligand chelating to one $\mathrm{Ni}^{\mathrm{II}}$ ion through the carbonyl $\mathrm{O}$ atom and the oximato $\mathrm{N}$ atom and bridging to another through the deprotonated oximato $\mathrm{O}$ atom. Six $\mu_{3}-\mathrm{MeO}^{-}$ligands $\left(\mathrm{O}_{71}, \mathrm{O}_{72}\right.$ and $\left.\mathrm{O}_{73}\right)$ bridge the peripheral, face-capping $\mathrm{Ni}^{\mathrm{II}}$ ions to the central core. The octahedral environment around these peripheral $\mathrm{Ni}^{\mathrm{II}}$ ions is completed by two $\mathrm{MeOH}$ molecules and a terminal $\mathrm{MeCO}_{2}{ }^{-}$ligand. Alternatively, the metal core of the octanuclear cage may be described as being composed of two "corner" sharing cubanes, with the shared "corner" being the $\mu_{6}-\mathrm{O}_{2}{ }^{2-}$ moiety (Figure 1 ). The presence of abmo' corroborates the absence of the hydrogen atom at the carbonyl carbon atom and the short C...O distance (i.e. $1.243(7), 1.246(7)$ and $1.253(6) \AA$ for each of the three ab$\mathrm{mo}^{-}$ligands) and the presence of a $\mathrm{C}=\mathrm{O}$ bond. The $\eta^{3}: \eta^{3}: \mu_{6}-\mathrm{O}_{2}{ }^{2-}$ is fully surrounded by (six) $\mathrm{Ni}^{\mathrm{iI}}$ ions at the very center of the cage, and clearly templates the for- mation of the octanuclear cluster. It would appear highly unlikely that the octanuclear metal cage would form first, before $\mathrm{O}_{2}{ }^{2-}$ encapsulaltion. The $\mathrm{O}-\mathrm{O}$ bond length in the peroxide is 1.487(4) $\AA$, [1.508 $\AA$ in 2 and $1.491 \AA$ in 3] and is well within the limits of other reported peroxide bond lengths. ${ }^{1-9}$ The $\mathrm{Ni}-\mathrm{O}_{\text {peroxide }}$ bond lengths are 2.055(3) $\AA$, 2.031(3) $\AA$ and 2.015(3) $\AA$ for Ni1-O81, Ni2-O81 and Ni3O81, respectively with the $\mathrm{Ni}-\mathrm{O}_{\text {peroxide }}-\mathrm{Ni}$ angles being $114.61(13)^{\circ}, 97.58(12)^{\circ}$ and $113.09(13)^{\circ}$ for the Ni1-O81-Ni2, $\mathrm{Ni}-\mathrm{O} 81-\mathrm{Ni} 3$ and $\mathrm{Ni2}-\mathrm{O} 81-\mathrm{Ni} 3$ angles, respectively. The $\mathrm{Ni}-\mathrm{O} 81-\mathrm{O} 81^{\prime}$ angles are $111.47(19)^{\circ}, \quad 108.76(18)^{\circ}$ and $111.03(19)^{\circ}$ for $\mathrm{Ni}$, $\mathrm{Ni} 2$ and $\mathrm{Ni}$, respectively.
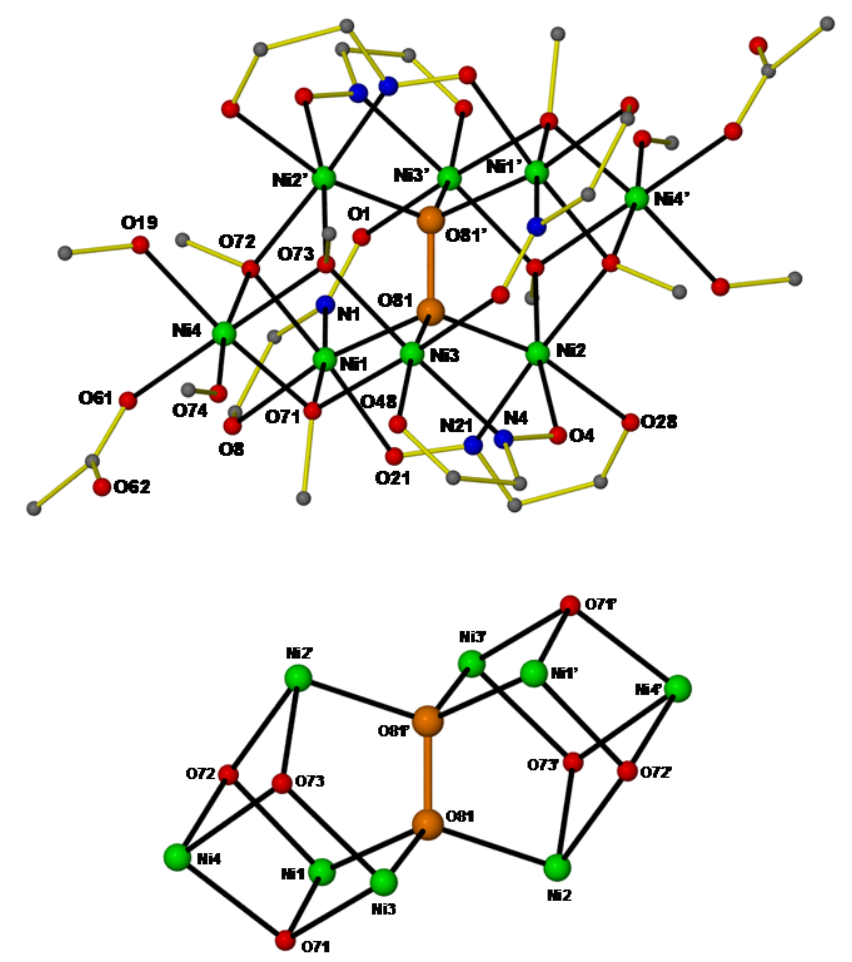

Figure 1. The structure of $\left[\mathrm{Ni}_{8}\left(\mathrm{O}_{2}\right)(\mathrm{abmo})_{6}\left(\mathrm{MeCO}_{2}\right)_{2}(\mathrm{MeO})_{6}\right.$ $\left.(\mathrm{MeOH})_{4}\right] \mathbf{~}$ (top). All hydrogen atoms and most carbon atoms have been omitted for clarity. A view of the metaloxygen core (bottom). Only the metal ions, the peroxide and the methoxide oxygen atoms are shown. Colour code: $\mathrm{Ni}$ green, $\mathrm{C}$ grey, $\mathrm{N}$ blue, $\mathrm{O}$ red. The $\eta^{3}: \eta^{3}: \mu_{6} \mathrm{O}_{2}{ }^{2-}$ has been highlighted in orange. Symmetry code: (') -x, $1-\mathrm{y},-\mathrm{z}$.

Complexes 1-3 join a handful of structurally characterized abmoH complexes ${ }^{12}$ and a very limited number of structurally characterized $\mathrm{Ni}^{\mathrm{iI}}$-peroxo complexes..$^{5 \mathrm{a}, \mathrm{a}, \mathrm{z}, \mathrm{b}, 8}$ Indeed the related complex $\left[\mathrm{Ni}_{8}\left(\mathrm{O}_{2}\right)(\mathrm{L})_{12}\right]\left(\mathrm{NO}_{3}\right)_{2}(\mathbf{5} ; \mathrm{LH}=$ $\mathrm{N}$-substituted 3-hydroxy-2-pyridinone), is the only other reported example containing the $\eta^{3}: \eta^{3}: \mu_{6}-\mathrm{O}_{2}{ }^{2-}$ ion. ${ }^{7 \mathrm{a}}$ The formation of this latter cluster was achieved only when $\mathrm{H}_{2} \mathrm{O}_{2}$ was added into the reaction mixture. The central $\mathrm{Ni}_{6}\left(\mathrm{O}_{2}\right)$ core in 5 is similar to that seen for 1-3, but with the two capping $\mathrm{Ni}^{\mathrm{II}}$ ions residing in the faces of the octahedron lying in the same plane as the $\mathrm{O}_{2}{ }^{2-}$ ion, rather than in the perpendicular plane for 1-3. Other dissimilarities are the square pyramidal coordination geometry 
around the central $\mathrm{Ni}^{\mathrm{II}}$ atoms and the absence of the $\mathrm{MeO}^{-}$bridges.

Complex 4 (Figure 2) crystallizes in the triclinic space group $P$-1. The $\left[\mathrm{Ni}_{5}\right]$ cluster is situated on an inversion center and consists of five coplanar $\mathrm{Ni}^{\mathrm{II}}$ atoms, two abo ${ }^{2-}$ and six aboH ${ }^{-}$ligands. The central $\mathrm{Ni}^{\mathrm{II}}$ atom (Ni1) is in a square planar geometry being chelated by the hydroxyl oxygen atoms and oximato nitrogen atoms from two $\eta^{2}: \eta^{1}: \eta^{1}: \mu_{3}$ abo ligands in a trans conformation. The hydroxyl $\mathrm{O}$ atom and the oximato $\mathrm{O}$ atom from both sides of the central Ni1 bridge $\mathrm{Niz}$ and its symmetry equivalent ion. $\mathrm{Niz}$ is in a distorted octahedral environment, being surrounded by a chelating $\mathrm{aboH}^{-}$ligand and the hydroxyl oxygen atoms from a cis- $\left[\mathrm{Ni}(\mathrm{aboH})_{2}\right]$ subunit. The latter consists of a square planar $\mathrm{Ni}^{\mathrm{iI}}$ ion $\left(\mathrm{Ni}_{3}\right)$ being chelated by two $\eta^{1}: \eta^{2}: \mu$ aboH ${ }^{-}$ligands through the hydroxyl oxygen atoms and the oximic nitrogen atoms in a cis configuration. Complex 4 is one of just a few structurally characterized aboH $_{2}$ complexes. $^{13}$

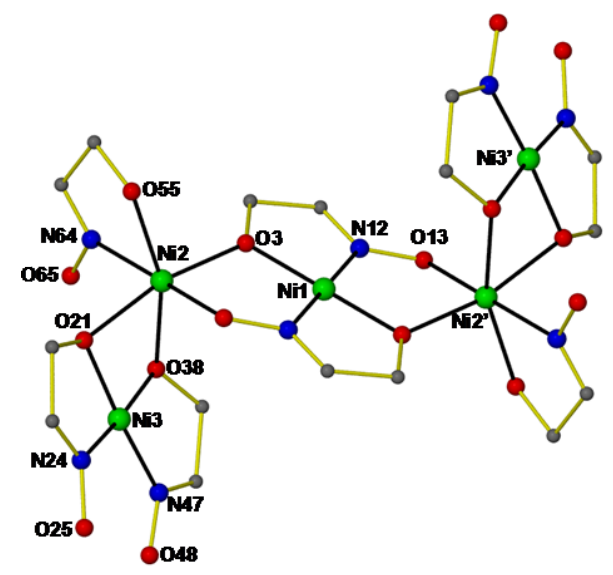

Figure 2. The structure of $\left[\mathrm{Ni}_{5}(\mathrm{abo})_{2}(\mathrm{aboH})_{6}\right]$ 4. All hydrogen atoms and most carbon atoms have been omitted for clarity. Color code: $\mathrm{Ni}$ green, $\mathrm{C}$ grey, $\mathrm{N}$ blue, $\mathrm{O}$ red. Symmetry code: (') $1-x,-y, 1-z$.

Raman Spectroscopy. The Raman spectra for the comparison of the ${ }^{16} \mathrm{O}(\mathbf{2} \cdot \mathbf{2} \mathrm{MeOH})$ and ${ }^{18} \mathrm{O}(\mathbf{2} \mathbf{A} \cdot 2 \mathrm{MeOH})$ complexes were collected for all samples on two different Raman spectrometers, both with $785 \mathrm{~nm}$ excitation. Although we used two different Raman spectrometers and varied both the exposure times and accumulation numbers in order to try and attain the optimal signal to noise $(\mathrm{S} / \mathrm{N})$ ratio in the Raman spectra we did not observe any shifts in the respective spectra in order to determine the peroxide stretching frequency (Figures $\mathrm{S}_{3}$ and $\mathrm{S}_{4}$ in the Supporting Information). Moreover, no Raman band was found to be sensitive to isotopic substitution with ${ }^{18} \mathrm{O}$ in the known $\left[\mathrm{Ni}_{8}\left(\mathrm{O}_{2}\right)(\mathrm{L})_{12}\right]\left(\mathrm{NO}_{3}\right)_{2}$ cluster. $^{7 \mathrm{a}}$

Mass spectrometry. Both the unlabelled (2) and ${ }^{18} \mathrm{O}-$ labelled $(\mathbf{2 A})$ complexes were observed as both $1+$ and $2+$ species where one or both benzoate ligands were lost. A shift of 4 units was observed in the spectrum of $\mathbf{2 A}$ compared to the spectrum of $\mathbf{2}$, with this shift correlating to the labelling of both oxygens of the peroxo ligand (see
Figure 3 and Tables 2 and 3 for mass spectra and assignments).

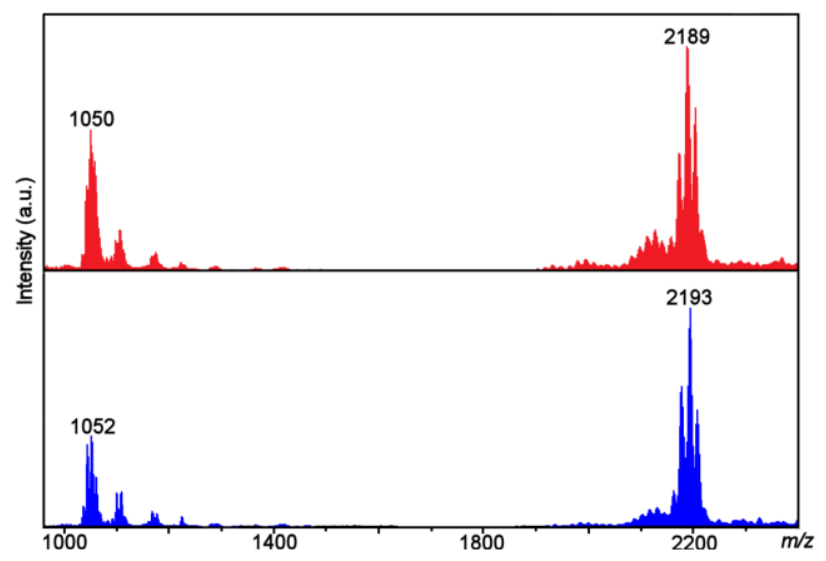

Figure 3. ESI-MS of $\mathbf{2}$ (top, red) and $\mathbf{2 A}$ (bottom, blue) showing the observation of the unlabelled and ${ }^{18} \mathrm{O}$ labelled $\left[\mathrm{Ni}_{8}\right]$ complex.

Magnetic Properties. Variable-temperature magnetic susceptibility data for the representative cage $\mathbf{1}$ were recorded between 250 and $5 \mathrm{~K}$ in an applied field of $1.0 \mathrm{kG}$. The plots of $\chi_{\mathrm{M}} T$ versus $T$ and $\chi_{\mathrm{M}}$ versus $T$ for $\mathbf{1}$ are shown in Figure 4 . The $\chi_{\mathrm{M}} T$ product for complex 1 decreases upon cooling from a value of $7.88 \mathrm{~cm}^{3} \mathrm{~K} \mathrm{~mol}^{-1}$ at $250 \mathrm{~K}$ to a value of $0.76 \mathrm{~cm}^{3} \mathrm{~K} \mathrm{~mol}^{-1}$ at $5 \mathrm{~K}$. The shape of the curve as well as the low value of the $\chi_{\mathrm{M}} T$ product at $5 \mathrm{~K}$ suggest the presence of dominant antiferromagnetic exchange interactions and a diamagnetic spin ground state. The experimental data were satisfactorily fitted using a simple one exchange parameter $(J)$ model by employing spin Hamiltonian (1). The best fit parameters were $J=-5.45 \mathrm{~cm}^{-1}$ and $g=2.20$.

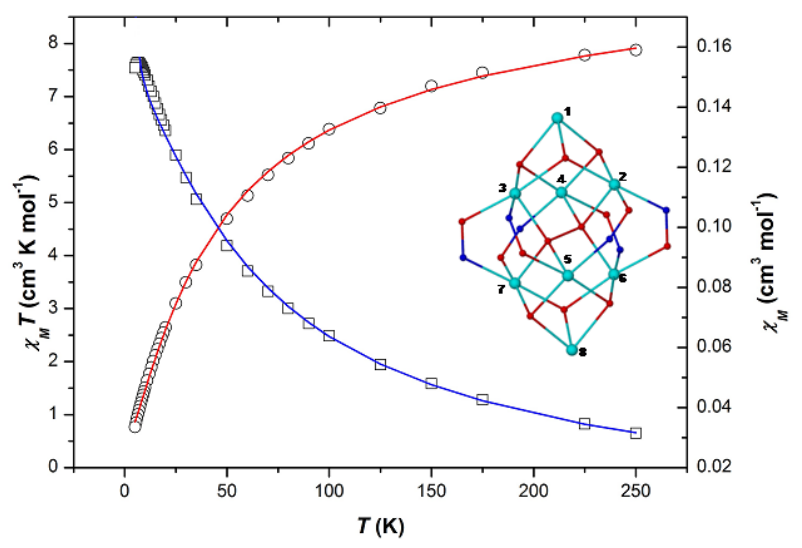

Figure $4 \cdot \chi_{\mathrm{M}} T$ vs. $T(\circ)$ and $\chi_{\mathrm{M}} T$ vs. $T(\square)$ plots for complex 1. The solid red and blue lines represent fits of the experimental data to spin-Hamiltonian (1) and the the model shown in the inset - see text for details.

$\hat{H}=-2 J\left(\hat{S}_{1} \cdot \hat{S}_{2}+\hat{S}_{1} \cdot \hat{S}_{3}+\hat{S}_{1} \cdot \hat{S}_{4}+\hat{S}_{2} \cdot \hat{S}_{3}+\hat{S}_{2} \cdot \hat{S}_{4}+\hat{S}_{2} \cdot \hat{S}_{5}+\hat{S}_{2} \cdot \hat{S}_{6}+\right.$ $\hat{S}_{3} \cdot \hat{S}_{4}+\hat{S}_{3} \cdot \hat{S}_{5}+\hat{S}_{3} \cdot \hat{S}_{7}+\hat{S}_{4} \cdot \hat{S}_{5}+\hat{S}_{4} \cdot \hat{S}_{6}+\hat{S}_{4} \cdot \hat{S}_{7}+\hat{S}_{5} \cdot \hat{S}_{6}+\hat{S}_{5} \cdot \hat{S}_{7}$ $\left.+\hat{S}_{5} \cdot \hat{S}_{8}+\hat{S}_{6} \cdot \hat{S}_{7}+\hat{S}_{6} \cdot \hat{S}_{8}+\hat{S}_{7} \cdot \hat{S}_{8}\right)$

Thermal Properties. Complexes 1-3 are stable in the solid-state, can be handled in air and stored at room temperature as powdered samples or as single-crystals within 
their mother liquor for a period of over two years. Thermogravimetric analysis (TGA, Figure 5) reveals that the three $\left[\mathrm{Ni}_{8}\right]$ cages are stable up to $200{ }^{\circ} \mathrm{C}$. This is an abnormal behaviour for peroxide complexes ${ }^{7 \mathrm{a}}$ and is attributed to the isolation of the $\mu_{6}-\mathrm{O}_{2}{ }^{2-}$ within the cores of the $\left[\mathrm{Ni}_{8}\right]$ cages.

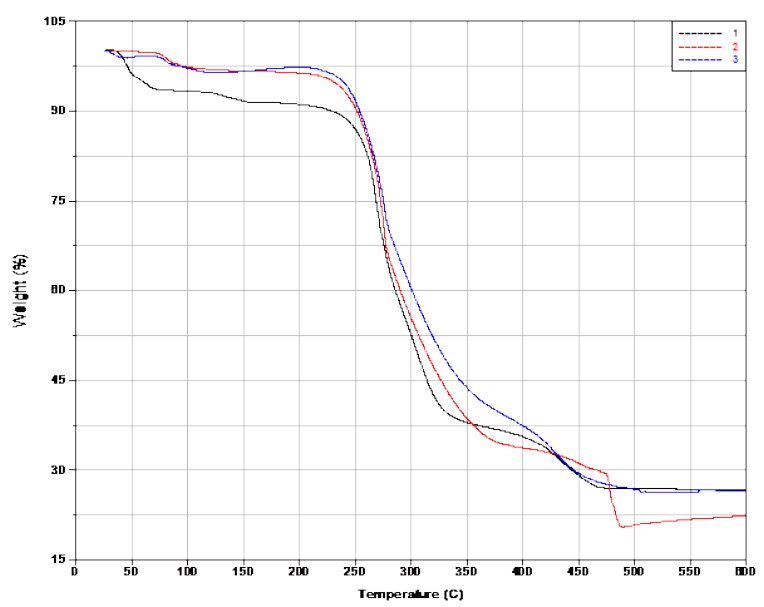

Figure 5. TGA plots in the $25-600{ }^{\circ} \mathrm{C}$ of $\mathbf{1}-\mathbf{3}$.

\section{CONCLUSIONS}

In summary, we report the synthesis and X-ray characterization of a family of octanuclear $\mathrm{Ni}^{\mathrm{II}}$ cages which are templated by a rare $\eta^{3}: \eta^{3}: \mu_{6}-\mathrm{O}_{2}{ }^{2-}$ produced by dioxygen activation. This is the first time the $\mathrm{O}_{2}{ }^{2-}$ (i.e. the reduced species) and the reducing agent for the $\mathrm{O}_{2}$ reduction which is not the metal ion - (i.e. the organic ligand found within the nickel cages in its oxidized form) were isolated and characterized by X-ray crystallography within the same compound(s). Cages 1-3 also represent unique paradigms of $\mathrm{O}_{2}$ activation and reduction by $\mathrm{Ni}^{\mathrm{II}}$ reaction blends, which means that the electrons needed to reduce the dioxygen into the $\mathrm{O}_{2}{ }^{2-}$ are not provided by the metal ion but by the organic ligand ${ }^{2 \mathrm{~s}, 2 \mathrm{t}, 2 \mathrm{x}}\left(\right.$ i.e. $\mathrm{aboH}_{2}$ ) which was found in its oxidized form (i.e. abmoH) within the cages. An alternative route providing access to the same $\left[\mathrm{Ni}_{8}\right]$ cages involves the use of the oxidized form of the ligand (i.e. abmoH) along with $\mathrm{H}_{2} \mathrm{O}_{2}$. The octanuclear cages are the first examples of polynuclear metal complexes which can be made from different organic ligands (i.e. $\mathrm{aboH}_{2}$ and $\mathrm{abmoH}$ ), and are exceptionally thermally stable (up to $200{ }^{\circ} \mathrm{C}$ ). They also increase the number of the structurally characterized $\mathrm{Ni}^{\mathrm{II}}$-peroxo compounds from four ${ }^{5 \mathrm{a}, 7 \mathrm{a}, 7 \mathrm{~b}, 8}$ to seven. The vibrational modes of the $\mu_{6}-\mathrm{O}_{2}{ }^{2-}$ were not identified by Raman spectroscopy since no band was sensitive to isotopic substitution with ${ }^{18} \mathrm{O}$; similarly no Raman band was found to be sensitive to isotopic substitution with ${ }^{18} \mathrm{O}$ in the known $\left[\mathrm{Ni}_{8}\left(\mu_{6}-\mathrm{O}_{2}\right)(\mathrm{L})_{12}\right]\left(\mathrm{NO}_{3}\right)_{2}$ cluster. ${ }^{\text {7a }}$ On the contrary, a shift of 4 units was observed in the ESI-MS spectrum of the ${ }^{18} \mathrm{O}$-labelled $\mathbf{2 A}$ compared to the spectrum of unlabelled 2 . This shift correlates to the labelling of both oxygens of the peroxo ligand, thus providing direct evidence that the peroxide originates from the reduction dioxygen. Magnetic susceptibility revealed relatively weak antiferromagnetic exchange inter- actions between neighboring $\mathrm{Ni}^{\mathrm{II}}$ ions, resulting in a diamagnetic spin ground state. The side product, a $\left[\mathrm{Ni}_{5}\right]$ cluster, was also isolated and characterized by X-ray crystallography. We are currently exploring the coordination chemistry of $\mathrm{aboH}_{2}$ and $\mathrm{abmoH}$ with other $3 \mathrm{~d}$ and $4 \mathrm{f}$ ions while examining the chemical reactivity of the $\left[\mathrm{Ni}_{8}\right]$ cages.

\section{ASSOCIATED CONTENT}

Supporting Information. Crystallographic data in CIF format for complexes 1-4 and supplementary figures. This material is available free of charge via the Internet at http://pubs.acs.org.

\section{AUTHOR INFORMATION}

Corresponding Author

ebrechin@staffmail.ed.ac.uk; gspapaef@chem.uoa.gr

\section{ACKNOWLEDGMENT}

This research has been co-financed by the European Union (European Social Fund - ESF) and Greek national funds through the Operational Program "Education and LifelongLearning" of the National Strategic Reference Framework (NSRF) - Research Funding Program: THALES. Investing in knowledge society through the European Social Fund. The BODOSSAKI FOUNDATION is also acknowledged for donating the TGA instrument to the Dept. of Chemistry of UoA.

\section{REFERENCES}

(1) (a) For a special issue on dioxygen activation by metalloenzymes and models, read: Nam W. (ed.) Acc. Chem. Res., 2007, 40, 465-634. (b) For a forum on dioxygen activation and reduction, read: Inorg. Chem., 2010, 49, 3555-3675.

(2) (a) Valentine, J. S. Chem. Rev. 1973, 73, 235-245. (b) Vaska L. Acc. Chem. Res. 1976, 9, 175-183. (c) Reim J.; Werner R.; Haase W.; Krebs B. Chem. Eur. J. 1998, 4, 289-298. (d) Cramer C. J.; Tolman, W. B.; Theopold, K. H.; Rheingold, A. L. Proc.Nat. Acad. Sci. 2003, 100, 3635-3640. (e) Kieber-Emmons, M. T.; Schenker, R.; Yap, G. P.; Brunold, T. C.; Riordan, C. G. Angew. Chem. Int. Ed. 2004, 43, 6716-6718. (f) Hikichi, S.; Okuda, H.; Ohzu, Y.; Akita, M. Angew. Chem. Int. Ed. 2009, 48, 188-191. (g) Liu, J. G.; Ohta, T.; Yamaguchi, S.; Ogura, T.; Sakamoto, S.; Maeda, Y.; Naruta, Y. Angew. Chem. Int. Ed. 2009, 48, 9262-9267. (h) Holland, P. L. Dalton Trans. 2o1o, 39, 5415-5425. (i) Sarangi, R.; Cho, J.; Nam, W.; Solomon, E. I. Inorg. Chem. 2011, 50, 614-620. (j) Yao, S.; Herwig, Y.; Xiong, C.; Company, A.; Bill, E.; Limberg, C.; Driess, M. Angew. Chem. Int. Ed. 2010, 49, 7054-7058. (k) Bochevarov, A. D.; Li, J.; Song, W. J.; Friesner, R. A.; Lippard, S. J. J. Am. Chem. Soc. 2011, 133, 7384-7397. (l) Cho, J.; Jeon, S.; Wilson, S. A.; Liu, L. V.; Kang, E. A.; Braymer, J. J.; Lim, M. H.; Hedman, B.; Hodgson, K. O.; Valentine, J. S.; Solomon, E. I.; Nam, W. Nature 2011, 478, 502-505. (m) Park, Y. J.; Ziller, J. W.; Borovik, A. S. J. Am. Chem. Soc. 2011, 133, 9258-9261. (n) Solomon, E. I.; Ginsbach, J. W.; Heppner, D. E.; Kieber-Emmons, M. T.; Kjaergaard, C. H.; Smeets, P. J.; Tian, L.; Woertink, J. S. Faraday Discuss. 2011, 148, 11. o) Tinberg, C. E.; Lippard, S. J. Acc. Chem. Res. 2011, 44, 280-288. p) Boisvert, L.; Goldberg, K. I. Acc. Chem.. Res. 2012, 45, 899-910. (q) Maji, S.; Lee, J. C.; Lu, Y. J.; Chen, C. L.; Hung, M. C.; Chen, P. P.; Yu, S. S.; Chan, S. I. Chem. Eur. J. 2012, 18, 3955-3968. (r) Yao, S.; Driess, M. Acc. Chem. Res. 2012, 45, 276-287. (s) Dong, G.; Shaik, S.; Lai, W. Chem. Sci. 2013, 4, 36243635. (t) Dong, G.; Lai, W. J. Phys. Chem. B 2014, 118, 1791-1798. 
(x) Fielding, A. J.; Lipscomb, j. D; Que L. J. Biol. Inorg. Chem. 2014, in press: DOI: 10.1007/soo775-014-1122-9.

(3) (a) Latifi, R.; Tahsini, L.; Kumar, D.; Sastry, G. N.; Nam, W.; de Visser, S. P. Chem. Commun. 2o11, 47, 10674-10676. (b) Zhou, M.; Crabtree, R. H. Chem. Soc. Rev. 2011, 40, 1875-1884. (c) Xiong, Y.; Yao, S.; Muller, R.; Kaupp, M.; Driess, M. Nat. Chem. 2010, 2, 577-580. (d) Citek, C.; Lyons, C. T.; Wasinger, E. C.; Stack, T. D. Nat. Chem. 2012, 4, 317-322. (e) Mirica, L. M.; Vance, M.; Rudd, D. J.; Hedman, B.; Hodgson, K. O.; Solomon, E. I.; Stack, T. D. Science 2005, 308, 1890-1892. (f) Reedijk, J. Science 2005, 308, 1876-1877. (g) Rolff, M.; Hamann, J. N.; Tuczek, F. Angew. Chem. Int. Ed. 2011, 5o, 6924-6927.

(4) (a) Jeske, P.; Haselhorst, G.; Weyhermueller, T.; Wieghardt, K.; Nuber, B. Inorg. Chem. 1994, 33, 2462-2471. (b) Cozzolino, A. F.; Tofan, D.; Cummins, C. C.; Temprado, M.; Palluccio, T. D.; Rybak-Akimova, E. V.; Majumdar, S.; Cai, X.; Captain, B.; Hoff, C. D. J. Am. Chem. Soc. 2012, 134, 18249-18252. (c) Yokoyama, A.; Eun Han, J.; Cho, J.; Kubo, M.; Ogura, T.; Siegler, M. A.; Karlin, K. D.; Nam, W. J. Am. Chem. Soc. 2012, 134, 1526915272. (d) Coggins, M. K.; Sun, X.; Kwak, Y.; Solomon, E. I.; Rybak-Akimova, E.; Kovacs, J. A. J. Am. Chem. Soc. 2013, 135, 5631-5640. (e) Lee, C. -M.; Chuo, Chen, C. -H.; Hu, C. -C.; Chiang, M. -H.; Tseng, Y. -J.; Hu, C. -H.; Lee, G. -H. Angew. Chem. Int. Ed. 2012, 51, 5427-5430. (f) Kim, K.; Lippard, S. J. J. Am. Chem. Soc. 1996, 118, 4914-4915. (g) Bouwman, E.; Driessen, W. L. J. Am. Chem. Soc. 1988, 110, 4440-4441. (h) Schmidt, S.; Heinemann, F. W.; Grohmann, A. Eur. J. Inorg. Chem. 2ooo, 1657-1667. (i) Gavrilova, A. L.; Jin Qin, C.; Sommer, R. D.; Rheingold, A. L.; Bosnich, B. J. Am. Chem. Soc. 2002, 124, 1714-1722. (j) Leznoff, D. B.; Katz, M. J.; Cheng, L. K. L.; Draper, N. D.; Batchelor, R. J. J. Mol. Struct. 2oo6, 796, 223-229. (k) Givaja, G.; Volpe, M.; Edwards, M. A. Blake, A. J.; Wilson, C.; Schröder, M.; Love, J. B. Angew. Chem. Int. Ed. 2007, 46, 584-586. (1) Kodera, M.; Katayama, K.; Tachi, Y.; Kano, K.; Hirota, S.; Fujinami, S.; Suzuki, M. J. Am. Chem. Soc. 1999, 121, 11006-11007. (m) Meyer, F.; Pritzkow, H. Angew. Chem. Int. Ed. 2000, 39, 2112-2115.

(5) (a) Matsumoto, M.; Nakatsu, K. Acta Cryst. 1975, B31, 27112713. (b) Yao, S.; Bill, E.; Milsmann, C.; Wieghardt, K.; Driess, M. Angew. Chem. Int. Ed. 2008, 47, 7110-7113.

(6) (a) Wilke, G.; Schott, H.; Heimbach, P. Angew. Chem. Int Ed. 1967, 6, 92-93. (b) Otsuka, S.; Nakamura, A.; Tatsuno, Y. J. Am. Chem. Soc. 1969, 91, 6994-6999. (c) Fujita, K.; Schenker, R.; Gu, W.; Brunold, T. C.; Cramer, S. P.; Riordan, C. G. Inorg. Chem. 2004, 43, 3324-3326. (d) Kieber-Emmons, M. T.; Annaraj, J.; Sook Seo, M.; Van Heuvelen, K. M.; Tosha, T.; Kitagawa, T.; Brunold, C.; Nam, W.; Riordan, C. G. J. Am. Chem. Soc. 2006, 128, 1423014231. (e) Kieber-Emmons, M. T.; Riordan, C. G. Acc. Chem. Res. 2007, 40, 618-625. (f) Company, A.; Yao, S.; Ray, K.; Driess, M. Chem. Eur. J. 2010, 16, 9669-9675.

(7) (a) Brown, E. J.; Duhme-Klair, A. K.; Elliott, M. I.; ThomasOates, J. E.; Timmins, P. L.; Walton, P. H. Angew. Chem. Int. Ed. 2005, 44, 1392-1395. (b) Cho, J.; Sarangi, R.; Annaraj, J.; Kim, S. Y.; Kubo, M.; Ogura, T.; Solomon, E. I.; W. Nam, Nat. Chem., 2oo9, 1, 568-572. (c) Shiren, K.; Ogo, S.; Fujinami, S.; Hayashi, H.; Suzuki, M.; Uehara, A.; Watanabe, Y.; Moro-oka, Y. J. Am. Chem. Soc. 200o, 122, 254-262. (d) Cho, J.; Furutachi, H.; Fujinami, S.; Tosha, T.; Ohtsu, H.; Ikeda, O.; Suzuki, A.; Nomura, M.; Uruga, T.; Tanida, H.; Kawai, T.; Tanaka, K.; Kitagawa, T.; Suzuki, M. Inorg. Chem. 20oo, 46, 2873-2885.

(8) Yao, S.; Xiong, Y.; Vogt, M.; Grutzmacher, H.; Herwig, C.; Limberg, C.; Driess, M. Angew. Chem. Int. Ed. 2009, 48, 81078110.

(9) (a) Auld, Jones, A. C.; Leese, A. B.; Cockayne, B.; Wright, P. J.; O'Brien, P.; Motevalli, M. J. Mater. Chem. 1993, 3, 1203-1208. (b) Hovnaninian, N.; Galloy, J.; Miele, P. Polyhedron 1995, 14, 297-300. (c) Sofetis, A.; Fotopoulou, F.; Raptopoulou, C. P.; Th. Zafiropoulos, F.; Perlepes, S. P.; Klouras, N. Polyhedron 2009, 28, 3356-336o. (d) Tolis, E. I.; Helliwell, M.; Langley, S.; Raftery, J.; Winpenny, R. E. P. Angew. Chem. Int. Ed. 2003, 42, 3804-3808.

(10) Catterick, J.; Thornton, P. J. Chem. Soc. Dalton Trans., 1975, 233-238.

(11) Taylor, T. W. J.; Marks, M. S. J. Chem. Soc. 1930, 2302-2307.

(13) (a) Sharutin, V. V.; Molokova, O. V.; Sharutina, O. K.; Akimova, T. I.; Gerasimenko, A. V.; Pushilin, M. A. Russ. J. Coord. Chem. 2004, 30, 559-565. (b) E. Soleimani, Rev. Chim. 2009, 6o, 484-487.

(14) (a) Karotsis, G.; Stoumpos, C.; Collins, A.; White, F.; Parsons, S.; Slawin, A. M.; Papaefstathiou, G. S.; Brechin, E. K. Dalton Trans. 2009, 3388-3390. (b) Koumousi, E. S.; Manos, M. J.; Lampropoulos, C.; Tasiopoulos, A. J.; Wernsdorfer, W.; Christou, G.; Stamatatos, T. C.; Inorg. Chem. 2010, 49, 3077-3079. (c) Liu, S.; Zhu, H.; Zubieta, J. Polyhedron 1989, 8, 2473-248o. (d) Stamatatos, T. C.; Vlahopoulou, G.; Raptopoulou, C. P.; Psycharis, V.; Escuer, A.; Christou, G.; Perlepes, S. P. Eur. J. Inorg. Chem. 2012, 3121-3131. (e) Vlahopoulou, G.; Stamatatos, T. C.; Psycharis, V.; Perlepes, S. P.; Christou, G. Dalton Trans. 2009, 3646-3649. 
Table 1. Crystallographic data for complexes 1-4

\begin{tabular}{|c|c|c|c|c|}
\hline Compound reference & $1 \cdot 4 \mathrm{H}_{2} \mathrm{O}$ & $2 \cdot 2 \mathrm{MeOH}$ & 3 & $4 \cdot 4 \mathrm{MeOH} \cdot \mathrm{CH}_{2} \mathrm{Cl}_{2}$ \\
\hline Chemical formula & $\mathrm{C}_{98} \mathrm{H}_{108} \mathrm{~N}_{6} \mathrm{Ni}_{8} \mathrm{O}_{32}$ & $\mathrm{C}_{110} \mathrm{H}_{112} \mathrm{~N}_{6} \mathrm{Ni}_{8} \mathrm{O}_{30}$ & $\mathrm{C}_{106} \mathrm{H}_{98} \mathrm{Cl}_{2} \mathrm{~N}_{6} \mathrm{Ni}_{8} \mathrm{O}_{28}$ & $\mathrm{C}_{117} \mathrm{H}_{112} \mathrm{Cl}_{2} \mathrm{~N}_{8} \mathrm{Ni}_{5} \mathrm{O}_{20}$ \\
\hline Formula Mass & 2351.58 & 2467.74 & 2444.48 & 2314.67 \\
\hline Crystal system & Triclinic & Monoclinic & Triclinic & Triclinic \\
\hline$a / \AA$ & $13.291(2)$ & $13.259(2)$ & $13.372(10)$ & $12.8976(6)$ \\
\hline$b / \AA$ & $13.838(2)$ & 28.761(5) & $14.701(11)$ & $13.0924(6)$ \\
\hline$c / \AA ̊$ & $16.545(4)$ & $15.273(3)$ & $15.110(11)$ & $16.4651(6)$ \\
\hline$\alpha /^{\circ}$ & 108.734(3) & 90.00 & $94.446(6)$ & 98.686(3) \\
\hline$\beta 1^{\circ}$ & $105.788(3)$ & $103.829(2)$ & 108.768(13) & 99.661(3) \\
\hline $2 /{ }^{\circ}$ & $101.737(2)$ & 90.00 & 104.964(10) & 90.904(3) \\
\hline Unit cell volume $/ \AA^{3}$ & 2628.1(8) & $5655.0(16)$ & $2675(3)$ & $2707.0(2)$ \\
\hline Temperature/K & $293(2)$ & $296(2)$ & $93(2)$ & 150.0 \\
\hline Space group & $P \overline{1}$ & $P 2(1) / c$ & $P \overline{1}$ & $P \overline{1}$ \\
\hline No. of formula units per unit cell, $Z$ & 1 & 2 & 1 & 1 \\
\hline Radiation type & $\mathrm{MoK} \alpha$ & $\mathrm{MoK} \alpha$ & $\mathrm{MoK} \alpha$ & $\mathrm{Cu} \mathrm{K} \alpha$ \\
\hline No. of reflections measured & 17894 & 21909 & 26876 & 54794 \\
\hline No. of independent reflections & 11581 & 8862 & 9695 & 9656 \\
\hline$R_{\text {int }}$ & 0.0352 & 0.0920 & 0.0381 & 0.0484 \\
\hline Final $R_{1}$ values $(I>2 \sigma(I))$ & 0.0542 & 0.0631 & 0.0601 & 0.0686 \\
\hline Final $w R\left(F^{2}\right)$ values $(I>2 \sigma(I))$ & 0.1391 & 0.1463 & 0.1644 & 0.1827 \\
\hline Final $R_{1}$ values (all data) & 0.0933 & 0.1197 & 0.0623 & 0.0829 \\
\hline Final $w R\left(F^{2}\right)$ values (all data) & 0.1603 & 0.1743 & 0.1669 & 0.2087 \\
\hline Goodness of fit on $F^{2}$ & 1.015 & 0.996 & 1.075 & 0.9640 \\
\hline
\end{tabular}

Table 2. Assigned formulae for the unlabelled complex 2

\begin{tabular}{|l|l|}
\hline $\boldsymbol{m} / \mathbf{z}$ & Formula \\
\hline 1034 & {$\left[\mathrm{Ni}_{8}\left(\mathrm{O}_{2}\right)(\mathrm{abmo})_{6}(\mathrm{MeO})_{6}\left(\mathrm{H}_{2} \mathrm{O}\right)_{2}\right]^{2+}$} \\
\hline 1041 & {$\left[\mathrm{Ni}_{8}\left(\mathrm{O}_{2}\right)(\mathrm{abmo})_{6}(\mathrm{MeO})_{6}\left(\mathrm{H}_{2} \mathrm{O}\right)(\mathrm{MeOH})\right]^{2+}$} \\
\hline 1050 & {$\left[\mathrm{Ni}_{8}\left(\mathrm{O}_{2}\right)(\mathrm{abmo})_{6}(\mathrm{MeO})_{6}\left(\mathrm{H}_{2} \mathrm{O}\right)_{2}(\mathrm{MeOH})\right]^{2+}$} \\
\hline 1059 & {$\left[\mathrm{Ni}_{8}\left(\mathrm{O}_{2}\right)(\mathrm{abmo})_{6}(\mathrm{MeO})_{6}\left(\mathrm{H}_{2} \mathrm{O}\right)_{3}(\mathrm{MeOH})\right]^{2+}$} \\
\hline 2171 & {$\left[\mathrm{Ni}_{8}\left(\mathrm{O}_{2}\right)(\mathrm{abmo})_{6}\left(\mathrm{PhCO} \mathrm{Ph}_{2}\right)(\mathrm{MeO})_{6}\left(\mathrm{H}_{2} \mathrm{O}\right)\right]^{+}$} \\
\hline 2189 & {$\left[\mathrm{Ni}_{8}\left(\mathrm{O}_{2}\right)(\mathrm{abmo})_{6}\left(\mathrm{PhCO}_{2}\right)(\mathrm{MeO})_{6}\left(\mathrm{H}_{2} \mathrm{O}\right)_{2}\right]^{+}$} \\
\hline 2203 & {$\left[\mathrm{Ni}_{8}\left(\mathrm{O}_{2}\right)(\mathrm{abmo})_{6}\left(\mathrm{PhCO}_{2}\right)(\mathrm{MeO})_{6}\left(\mathrm{H}_{2} \mathrm{O}\right)(\mathrm{MeOH})\right]^{+}$} \\
\hline
\end{tabular}

\section{Table 3. Assigned formulae for the ${ }^{18} \mathrm{O}$-labelled complex $2 \mathrm{~A}$}

\begin{tabular}{|l|l|}
\hline $\boldsymbol{m} / \boldsymbol{z}$ & Formula \\
\hline 1043 & $\left.\left[\mathrm{Ni}_{8}{ }_{8}{ }^{18} \mathrm{O}_{2}\right)(\mathrm{abmo})_{6}(\mathrm{MeO})_{6}\left(\mathrm{H}_{2} \mathrm{O}\right)(\mathrm{MeOH})\right]^{2+}$ \\
\hline 1052 & $\left.\left[\mathrm{Ni}_{8}{ }_{8}{ }^{18} \mathrm{O}_{2}\right)(\mathrm{abmo})_{6}(\mathrm{MeO})_{6}\left(\mathrm{H}_{2} \mathrm{O}\right)_{2}(\mathrm{MeOH})\right]^{2+}$ \\
\hline 1061 & $\left.\left[\mathrm{Ni}_{8}{ }_{8}{ }^{18} \mathrm{O}_{2}\right)(\mathrm{abmo})_{6}(\mathrm{MeO})_{6}\left(\mathrm{H}_{2} \mathrm{O}\right)_{3}(\mathrm{MeOH})\right]^{2+}$ \\
\hline 2175 & $\left.\left[\mathrm{Ni}_{8}{ }_{8}{ }^{18} \mathrm{O}_{2}\right)(\mathrm{abmo})_{6}\left(\mathrm{PhCO}_{2}\right)(\mathrm{MeO})_{6}\left(\mathrm{H}_{2} \mathrm{O}\right)\right]^{+}$ \\
\hline 2193 & $\left.\left[\mathrm{Ni}_{8}{ }_{8}{ }^{18} \mathrm{O}_{2}\right)(\mathrm{abmo})_{6}\left(\mathrm{PhCO}_{2}\right)(\mathrm{MeO})_{6}\left(\mathrm{H}_{2} \mathrm{O}\right)_{2}\right]^{+}$ \\
\hline 2207 & $\left.\left[\mathrm{Ni}_{8}{ }_{8}{ }^{18} \mathrm{O}_{2}\right)(\mathrm{abmo})_{6}\left(\mathrm{PhCO}_{2}\right)(\mathrm{MeO})_{6}\left(\mathrm{H}_{2} \mathrm{O}\right)(\mathrm{MeOH})\right]^{+}$ \\
\hline
\end{tabular}




\section{Table of Contents}
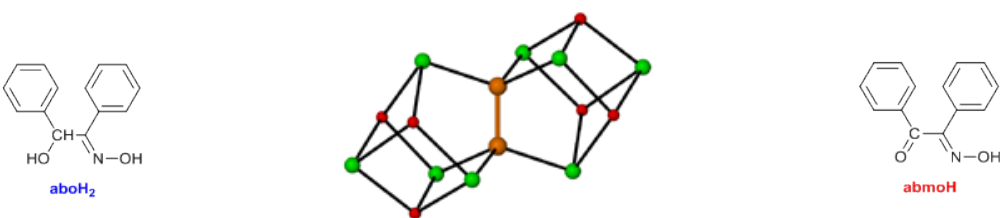

$\mathrm{Ni}\left(\mathrm{RCO}_{2}\right)_{2} / \mathrm{aboH}_{2} / \mathrm{Et}_{3} \mathrm{~N} / \mathrm{O}_{2}$

$\left[\mathrm{Ni}_{8}\left(\mathrm{O}_{2}\right)(\mathrm{ambo})_{6}\left(\mathrm{RCO}_{2}\right)_{2}(\mathrm{MeO})_{6}(\text { solvent })_{4}\right]$

$\mathrm{Ni}\left(\mathrm{RCO}_{2}\right)_{2} / \mathrm{abmoH} / \mathrm{Et}_{3} \mathrm{~N} / \mathrm{H}_{2} \mathrm{O}_{2}$

$\left[\mathrm{Ni}_{5}(\mathrm{abo})_{2}(\mathrm{aboH})_{6}\right]$ 